Article

\title{
Neo-5,22E-Cholestadienol Derivatives from Buthus martensii Karsch and Targeted Bactericidal Action Mechanisms
}

\author{
Biyu Lv ${ }^{1}$, Weiping Yin ${ }^{1, *}$, Jiayu Gao ${ }^{1}$, Huaqing Liu ${ }^{1}$, Kun Liu ${ }^{1}$, Jie Bai ${ }^{1}$ and Qiangqiang Yang ${ }^{2}$ \\ 1 School of Chemical Engineering and Pharmaceutics, Henan University of Science and Technology, \\ Luoyang 471023, China; biyulv0827@163.com (B.L.); cruise1024@163.com (J.G.); lhq@126.com (H.L.); \\ liukun1988china@163.com (K.L.); bj@126.com (J.B.) \\ 2 Life Science and Environmental Science Research Center of Harbin University of Commerce, Harbin 150025, \\ China; 18568105396@163.com \\ * Correspondence: yinwp@haust.edu.cn; Tel.: +86-379-642-31914
}

Academic Editor: Adel Nefzi

Received: 4 November 2018; Accepted: 20 December 2018; Published: 26 December 2018

check for updates

\begin{abstract}
The discovery and search for new antimicrobial molecules from insects and animals that live in polluted environments is a very important step in the scientific search for solutions to the current problem of antibiotic resistance. Previously, we have reported that the secondary metabolite with the antibacterial action discovered in scorpion. The current study further isolated three new compounds from Buthus martensii karsch, while compounds $\mathbf{1}$ and $\mathbf{2}$ possessed 5,22E-cholestadienol derivatives whose structure demonstrated broad spectrum bactericide activities. To explore the antibacterial properties of these new compounds, the result shows that compound 2 inhibited bacterial growth of both S. aureus and P. aeruginosa in a bactericidal rather than a bacteriostatic manner (MBC/MIC ratio $\leq 2$ ). Similarly, with compound 1 , a ratio of $\mathrm{MBC} / \mathrm{MIC} \leq 2$ indicates bactericidal activity inhibited bacterial growth of $P$. aeruginosa. Remarkably, this suggests that two compounds can be classified as bactericidal agents against broad spectrum bactericide activities for 5,22E-cholestadienol derivatives from Buthus martensii karsch. The structures of compounds 1-3 were established by comprehensive spectra analysis including two-dimensional nuclear magnetic resonance (2D-NMR) and high-resolution electrospray ionization-mass spectrometry (HRESI-MS) spectra. The antibacterial mechanism is the specific binding (various of bonding forces between molecules) using compound 1 or 2 as a ligand based on the different receptor proteins'-2XRL or 1Q23-active sites from bacterial ribosome unit $\mathrm{A}$, and thus prevent the synthesis of bacterial proteins. This unique mechanism avoids the cross-resistance issues of other antibacterial drugs.
\end{abstract}

Keywords: Buthus martensii karsch; secondary metabolites; novel 5,22E-cholestadienol compounds; broad-spectrum bactericide; natural products; structures elucidated; molecular docking; targeted action mechanisms

\section{Introduction}

The scorpion is an ancient arthropod and a source of bioactive functional ingredients, it has been traditionally long time used for medicinal benefits as analgesic and antitumor effects of scorpion toxin in traditional Chinese medicine (TCM). The secondary metabolites of insects and arthropods are an important resource for the study of natural products [1,2]. Insects, such as mosquito, flies, and bedbugs, adapted under the harshest living conditions on earth and developed bioactive secondary metabolites responding to environmental challenges [3]. However, due to the low content levels and difficulty of separation, the assessment of the diversity of active molecules and the identification of novel 
structures small molecular remain a continuing challenge. Previously, the secondary metabolites with antibacterial features have been isolated from insects, invertebrates and arthropod in our group [4-6]. It especially highlights the antibiotic potentials of secondary metabolites, including low-abundance analogs in natural products. The recent study investigated the antibacterial effects of the scorpion, Buthus martensii karsch and its secondary metabolites, thus three compounds (Figure 1) were firstly isolated and identified. Among them, two compounds deduced as the novel 5,22E-cholestadienol derivatives were determined to have the bactericidal abilities.

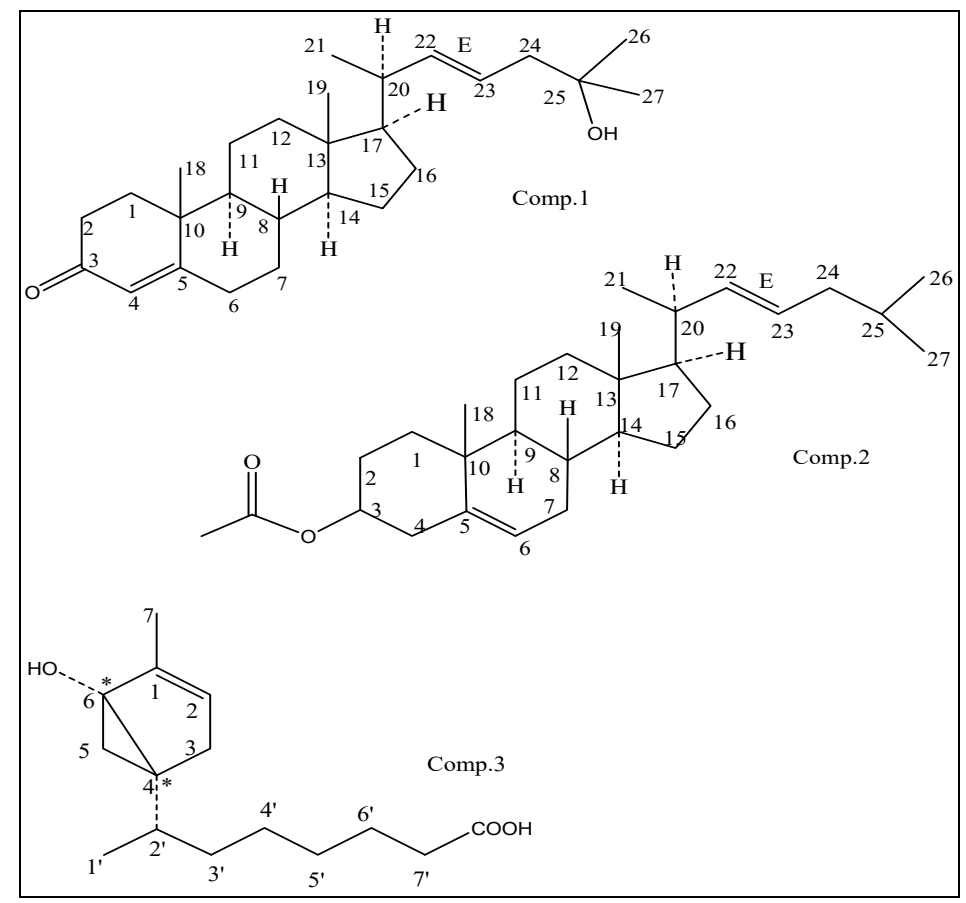

Figure 1. Structures of compounds 1-3 from arthropod scorpion, B. martensii kirsch.

\section{Results and Discussion}

\subsection{Chemistry}

The bioassay guided isolation using silica gel and preparative HPLC gave compounds $\mathbf{1}$ (35.0 mg), $2(29.1 \mathrm{mg})$, and 3 (24.6 $\mathrm{mg})$.

Compound 1 (QX75-5) was obtained as a white solid powder and assigned a molecular formula for $\mathrm{C}_{27} \mathrm{H}_{43} \mathrm{O}_{2}$ based on its positive HR-ESIMS ion at $[\mathrm{M}+\mathrm{H}]^{+} \mathrm{m} / z 399.3263$ (calcd. for 399.3258). Optical rotation of 1 was measured $[\alpha]_{D}^{25}-22.7^{\circ}\left(\mathrm{c}, 0.07, \mathrm{CHCl}_{3}\right)$ by a JASCO DIP-360 digital polarimeter. The IR spectrum of compound 1 suggested the presence of $\alpha, \beta$-unsaturated carbonyl group $\left(1678 \mathrm{~cm}^{-1}\right)$ and the double bond $\left(1583,1446\right.$, and $\left.690 \mathrm{~cm}^{-1}\right)$, a hydroxyl absorption (3346 and $\left.1110 \mathrm{~cm}^{-1}\right)$. The ${ }^{1} \mathrm{H}-\mathrm{NMR}$ $\left(400 \mathrm{MHz}, \mathrm{CDCl}_{3}\right)$ spectrum exhibited resonances multiple proton signals for the characteristics of sterols or triterpenoid compounds at $\delta_{H} 0.68-2.52$, besides which it can be seen the signal of a hydroxyl at $\delta_{H} 3.62$, and the double bonds at $\delta_{H} 5.69(1 \mathrm{H}, \mathrm{d}, 1.48 \mathrm{~Hz}), \delta_{H} 5.68(1 \mathrm{H}, \mathrm{dd}, 3.24,1.48 \mathrm{~Hz})$, and 5.20 $(1 \mathrm{H}, \mathrm{dd}, 7.60,3.28 \mathrm{~Hz})$ suggesting that compound 1 is a steroidalenol structure with $\alpha, \beta$-unsaturated carbonyl group combining the above IR data. The ${ }^{13} \mathrm{C}-\mathrm{NMR}$ and DEPT $\left(100 \mathrm{MHz}, \mathrm{CDCl}_{3}\right)$ spectra (Table 1) displayed resonances for 27 carbon signals and categorized as unsaturated double bond at $\delta c$ $135.6(\mathrm{CH}), 131.9(\mathrm{CH}), 126.1(\mathrm{CH})$; five methyl at $\delta_{C} 12.0,17.3,18.9,22.7$, and 22.8; four quaternary carbon signals at $\delta c 202.3(\mathrm{C}=\mathrm{O}), 165.1(\mathrm{C}), 70.5(\mathrm{C})$, and $42.3(\mathrm{C})$; tertiary carbon of six signal $\delta c 54.8$ $(\mathrm{CH}), 50.0(\mathrm{CH}), 45.4(\mathrm{CH}), 42.8(\mathrm{CH}), 36.3(\mathrm{CH})$, and $29.7(\mathrm{CH})$; alone with nine methylene carbon signals $\delta c 39.5\left(\mathrm{CH}_{2} \times 2\right), 38.7\left(\mathrm{CH}_{2}\right), 38.3\left(\mathrm{CH}_{2}\right), 35.7\left(\mathrm{CH}_{2}\right), 31.2\left(\mathrm{CH}_{2}\right), 28.1\left(\mathrm{CH}_{2}\right), 23.8\left(\mathrm{CH}_{2}\right)$, and $21.2\left(\mathrm{CH}_{2}\right)$. The observed HMBC correlations from H-4 $\left(\delta_{H} 5.68\right)$ to $\mathrm{C}-3\left(\delta_{C} 202.3\right) \mathrm{C}-4\left(\delta_{C} 126.1\right)$, 
and C-5 $\left(\delta_{C} 165.1\right), H-22\left(\delta_{H} 5.22\right)$, to $C-23\left(\delta_{C} 135.6\right)$, certified the presence of two double bonds at C-4 and C-22, respectively. In addition, the HMBC correlations from $\mathrm{H}-17\left(\delta_{H} 1.58\right)$ to $\mathrm{C}-12\left(\delta_{\mathrm{C}} 39.5\right)$ and C-21 $\left(\delta_{C} 18.9\right), \mathrm{H}-23\left(\delta_{H} 5.20,1 \mathrm{H}, \mathrm{dd}, 7.60,3.28 \mathrm{~Hz}\right)$ to $\mathrm{C}-25\left(\delta_{C} 70.5\right)$, revealed the $\beta$-configuration of C-21 methyl and one hydroxyl group joined on the C-25. The HMBC correlation of compound $\mathbf{1}$ is shown in Figure 2. From the above, compound $\mathbf{1}$ was confirmed as a novel cholesterolenone structure $[7,8]$ based on the analysis of spectral data of $\mathbf{1}$ and the comparison with the literature. Compound 1 was then named as (-) 22E, 3-oxocholesta-4, 22 (23)-dien-25-ol according to reported compound in the literature (+) (22E, 24 $\alpha$ )-24-Ethyl-3-oxocholesta-4, 22 (23)-dien-25-ol [9], which the latter for known compound has one ethyl group former on C-24 (for details in Figure 3).

Since the optical rotation $[\alpha]_{D}^{25}-22.7^{\circ}$ of compound 1 exhibited a negative Cotton effect at $223.5 \mathrm{~nm}$ for the determination of its CD spectra, and it was inferred to be a levorotatory configuration compound of enantiomers contrasted with known compound (+)7S, $8 S, 9 R, 13 R, 14 S, 17 R, 24 S, 20 R$ $(22 E, 24 \alpha)$-24-Ethyl-3-oxocholesta-4, 22(23)-dien-25-ol [9]. Accordingly, the structure of compound 1 was elucidated as a new cholestadienol shown and named as (-) 7S, 8S, 9R, 13R, 14S, 17R, $20 \mathrm{~S}$ (22E)-3-oxocholesta-4, 22(23)-dien-25-ol in Figure 1. Which the absolute stereochemistry can be seen from the NOESY spectrum, and the correlation crossover was at H-17ax $\left(\delta_{H} 1.58\right), \mathrm{H}-12 \mathrm{ax}\left(\delta_{H}\right.$ 1.96), and H-20eq $\left(\delta_{H} 1.18\right)$, from Me-21 to $\mathrm{H}-22\left(\delta_{H} 5.22\right)$; both H-17ax and H-20eq $\left({ }^{3} J_{\mathrm{H} 17-\mathrm{H} 20}\right)$ with $3.78,1.36 \mathrm{~Hz}$ in ${ }^{1} \mathrm{H}-\mathrm{NMR}$ were indicative of the $17 R, 20 S$, and $21 R$ configuration. Their absolute configurations were confirmed by comparing with known chiral analogs, C-24R orientation, and the $J$ values above analysis of chemical correlation in ${ }^{1} \mathrm{H}-\mathrm{NMR}$ spectrum. The ${ }^{1} \mathrm{H}-\mathrm{NMR}$ and ${ }^{13} \mathrm{C}-\mathrm{NMR}$ data assignment of compound $\mathbf{1}$ was shown in Table 1.

Table 1. ${ }^{1} \mathrm{H}-\mathrm{NMR}\left(400 \mathrm{MHz}\right.$ ) and ${ }^{13} \mathrm{C}-\mathrm{NMR}(100 \mathrm{MHz})$ data of compounds 1 and 2 (in $\mathrm{CDCl}_{3}$ ).

\begin{tabular}{|c|c|c|c|c|}
\hline \multirow{2}{*}{ No. } & \multicolumn{2}{|c|}{ Compound 1} & \multicolumn{2}{|c|}{ Compound 2} \\
\hline & $\delta_{H}(J, \mathrm{~Hz})$ & $\delta c(\mathrm{DEPT})$ & $\delta_{H}(J, \mathrm{~Hz})$ & $\delta c(\mathrm{DEPT})$ \\
\hline 1 & $1.57 \mathrm{~m}, 1.20 \mathrm{~m}$ & $38.3\left(\mathrm{CH}_{2}\right)$ & $1.02 \mathrm{~m}, 2.32 \mathrm{~m}$ & $36.2\left(\mathrm{CH}_{2}\right)$ \\
\hline 2 & $2.24(2 \mathrm{H}, \mathrm{m})$ & $35.7\left(\mathrm{CH}_{2}\right)$ & $1.86 \mathrm{~m}, 1.55 \mathrm{~m}$ & $27.2\left(\mathrm{CH}_{2}\right)$ \\
\hline 3 & - & $202.3(\mathrm{C})$ & $3.50 \mathrm{~m}$ & $71.8(\mathrm{CH})$ \\
\hline 4 & $5.69(1 \mathrm{H}, \mathrm{d}, 1.48)$ & $126.1(\mathrm{CH})$ & $1.82 \mathrm{~m}$ & $33.1\left(\mathrm{CH}_{2}\right)$ \\
\hline 5 & - & $165.1(\mathrm{C})$ & & $140.7(\mathrm{C})$ \\
\hline 6 & $2.39 \mathrm{~m}$ & $38.7\left(\mathrm{CH}_{2}\right)$ & $5.33(1 \mathrm{H}, \mathrm{dd}, 3.56,1.52)$ & $121.7(\mathrm{CH})$ \\
\hline 7 & $1.02 \mathrm{~m}, 1.93 \mathrm{~m}$ & $31.2\left(\mathrm{CH}_{2}\right)$ & $2.27 \mathrm{~m}, 1.25 \mathrm{~m}$ & $31.4\left(\mathrm{CH}_{2}\right)$ \\
\hline 8 & $1.60 \mathrm{~m}$ & $29.7(\mathrm{CH})$ & $1.56 \mathrm{~m}$ & $31.9(\mathrm{CH})$ \\
\hline 9 & $0.91 \mathrm{~m}$ & $45.4(\mathrm{CH})$ & $0.90 \mathrm{~m}$ & $50.1(\mathrm{CH})$ \\
\hline 10 & - & $42.3(\mathrm{C})$ & - & $36.2(\mathrm{C})$ \\
\hline 11 & $1.50 \mathrm{~m}, 1.33 \mathrm{~m}$ & $21.2\left(\mathrm{CH}_{2}\right)$ & $1.50 \mathrm{~m}, 1.06 \mathrm{~m}$ & $21.1\left(\mathrm{CH}_{2}\right)$ \\
\hline 12 & $1.18 \mathrm{~m}, 1.96 \mathrm{~m}$ & $39.5\left(\mathrm{CH}_{2}\right)$ & $1.30 \mathrm{~m}, 2.30 \mathrm{~m}$ & $39.7\left(\mathrm{CH}_{2}\right)$ \\
\hline 13 & - & $50.0(\mathrm{CH})$ & - & $56.1(\mathrm{CH})$ \\
\hline 14 & $0.90 \mathrm{~m}$ & $42.8(\mathrm{CH})$ & $2.33(1 \mathrm{H}, \mathrm{m})$ & $42.3(\mathrm{CH})$ \\
\hline 15 & $1.26 \mathrm{~m}, 2.40 \mathrm{~m}$ & $23.8\left(\mathrm{CH}_{2}\right)$ & $1.30 \mathrm{~m}, 2.30 \mathrm{~m}$ & $24.7\left(\mathrm{CH}_{2}\right)$ \\
\hline 16 & $1.36 \mathrm{~m}, 2.02 \mathrm{~m}$ & $28.1\left(\mathrm{CH}_{2}\right)$ & $1.86 \mathrm{~m}, 1.49 \mathrm{~m}$ & $28.5\left(\mathrm{CH}_{2}\right)$ \\
\hline 17 & $1.58(1 \mathrm{H}, \mathrm{dd}, 3.78,1.36)$ & $54.8(\mathrm{CH})$ & $1.16 \mathrm{~m}$ & $56.7(\mathrm{CH})$ \\
\hline 18 & $0.84 \mathrm{~s}$ & $12.0\left(\mathrm{CH}_{3}\right)$ & $0.84 \mathrm{~s}$ & $11.9\left(\mathrm{CH}_{3}\right)$ \\
\hline 19 & $0.78 \mathrm{~s}$ & $17.3\left(\mathrm{CH}_{3}\right)$ & $0.67 \mathrm{~s}$ & $18.7\left(\mathrm{CH}_{3}\right)$ \\
\hline 20 & $1.18(1 \mathrm{H}, \mathrm{dd}, 3.78,1.48)$ & $36.3(\mathrm{CH})$ & $1.06 \mathrm{~m}$ & $37.3(\mathrm{CH})$ \\
\hline 21 & $0.86 \mathrm{~s}$ & $18.9\left(\mathrm{CH}_{3}\right)$ & $0.97 \mathrm{~s}$ & $18.9\left(\mathrm{CH}_{3}\right)$ \\
\hline 22 & $5.68(1 \mathrm{H}, \mathrm{dd}, 3.24,1.48)$ & $131.9(\mathrm{CH})$ & $5.35(1 \mathrm{H}, \mathrm{dd}, 3.56,1.64)$ & $131.7(\mathrm{CH})$ \\
\hline 23 & $5.20(1 \mathrm{H}, \mathrm{dd}, 7.60,3.28)$ & $135.6(\mathrm{CH})$ & $5.16(1 \mathrm{H}, \mathrm{dd}, 6.68,3.56)$ & $135.8(\mathrm{CH})$ \\
\hline 24 & $1.33 \mathrm{~m}, 2.40 \mathrm{~m}$ & $39.5\left(\mathrm{CH}_{2}\right)$ & $1.12 \mathrm{~m}, 2.32 \mathrm{~m}$ & $29.7\left(\mathrm{CH}_{2}\right)$ \\
\hline 25 & $3.67(1 \mathrm{H}, \mathrm{m})$ & $70.5(\mathrm{C})$ & $2.27(1 \mathrm{H}, \mathrm{m})$ & $28.5(\mathrm{CH})$ \\
\hline 26 & $0.87 \mathrm{~s}$ & $22.7\left(\mathrm{CH}_{3}\right)$ & $1.03(3 \mathrm{H}, \mathrm{d}, 6.9)$ & $22.5\left(\mathrm{CH}_{3}\right)$ \\
\hline 27 & $0.90 \mathrm{~s}$ & $22.8\left(\mathrm{CH}_{3}\right)$ & $1.06(3 \mathrm{H}, \mathrm{d}, 6.9)$ & $22.8\left(\mathrm{CH}_{3}\right)$ \\
\hline$-\mathrm{OCO}$ & - & & - & $179.0(\mathrm{C})$ \\
\hline$-\mathrm{CH}_{3}$ & - & & $1.08(\mathrm{~s})$ & $28.0\left(\mathrm{CH}_{3}\right)$ \\
\hline
\end{tabular}




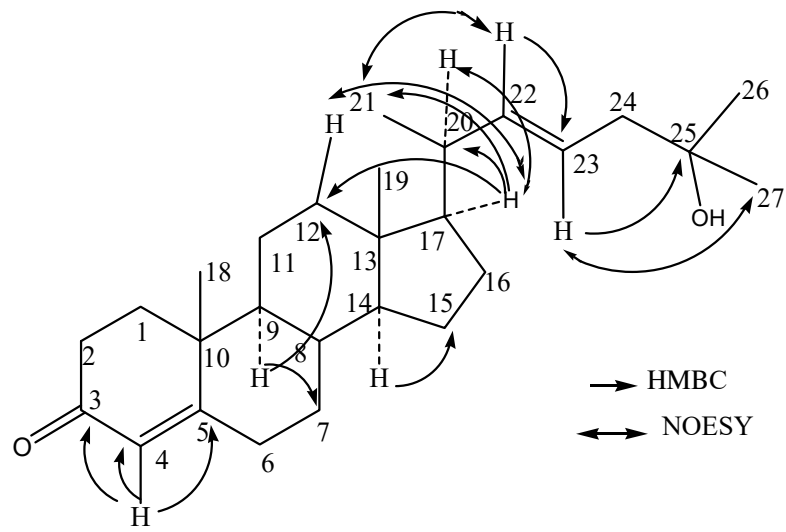

Figure 2. The key HMBC and NOESY correlations of compound 1.

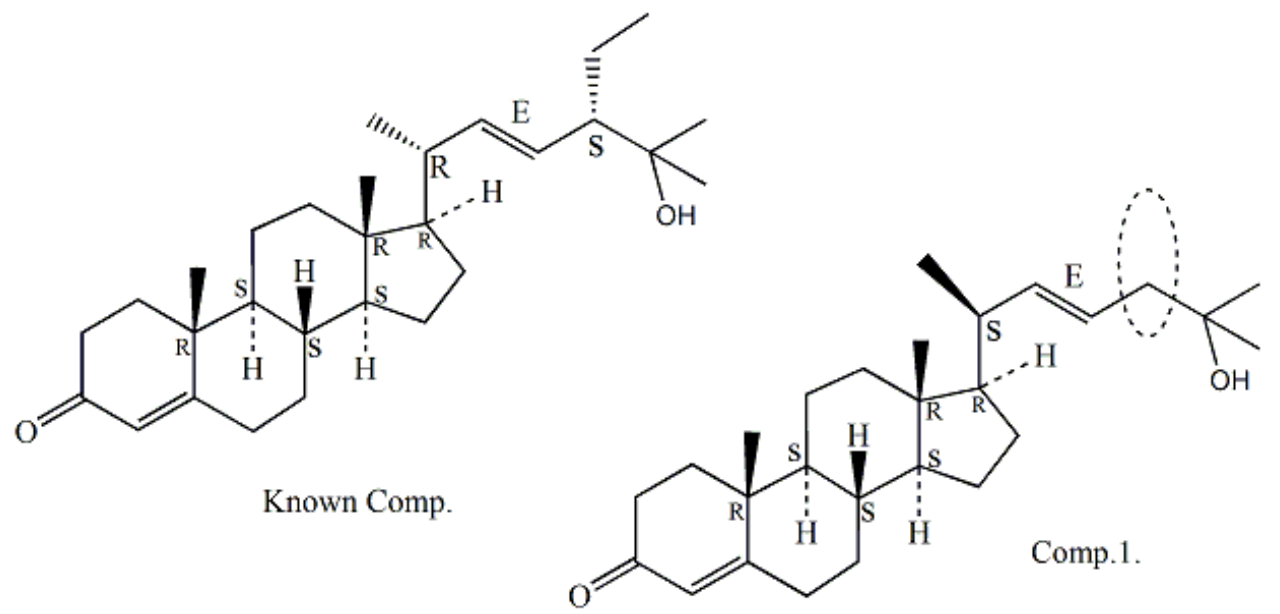

Figure 3. Structure of CAS No. 221012-56-2 and compound 1.

The HR-EIMS of compound 2 (QX37-45-4) exhibited $\mathrm{M}+\mathrm{H}^{+}$at $m / z$ 427.3568, which corresponded to the formula $\mathrm{C}_{29} \mathrm{H}_{47} \mathrm{O}_{2}$ (calcd. for 427.3571 ). It was a yellowish amorphous solid with optical rotation measured as $[\alpha]_{D}^{25}-66.7^{\circ}\left(\mathrm{c}, 0.10, \mathrm{CHCl}_{3}\right)$. The $\mathrm{CD}$ spectrum of compound 2 exhibited a negative Cotton effect at 222.5 and $254.8 \mathrm{~nm}(\mathrm{vw})$ (Figure 3), and its IR absorption bands at $3417 \mathrm{~cm}^{-1}$ and $1726 \mathrm{~cm}^{-1}$ and 1640,1568 , and $1447 \mathrm{~cm}^{-1}$ coincided with the double bond and ester group, respectively. The ${ }^{1} \mathrm{H}-\mathrm{NMR}\left(400 \mathrm{MHz}, \mathrm{CDCl}_{3}\right.$ ) and ${ }^{13} \mathrm{C}-\mathrm{NMR}$ and DEPT (100 MHz, $\mathrm{CDCl}_{3}$ ) spectra (Table 1) were similar to those of compound 1, implying that compound 2 was a derivative of the same skeleton of 1 with a ketone group replaced by ester group of $3 \beta$-acetoxyl group $\left[\mathrm{H}-3,\left(\delta_{H} 3.50,1 \mathrm{H}, \mathrm{m}\right)\right.$; C-3, $\left.\left(\delta_{C} 71.8, \mathrm{CH}\right)\right]$. There are the double bond signals in compound $\mathbf{1}$ with an isolated double bond at $\delta_{H} 5.33 \mathrm{H}-5(1 \mathrm{H}, \mathrm{dd}, 5.16 \mathrm{~Hz}, 3.24 \mathrm{~Hz})$ and $\delta_{\mathrm{C}} 121.7(\mathrm{C}-5, \mathrm{CH})$, and $\delta_{\mathrm{C}} 140.7(\mathrm{C}-4, \mathrm{C})$; and two others double bond signals both $\left.\delta_{H} 5.35 \mathrm{H}-22(1 \mathrm{H}, \mathrm{dd}, 3.56,1.64 \mathrm{~Hz})\right]$ and $\delta_{H} 5.16 \mathrm{H}-23(1 \mathrm{H}, \mathrm{dd}, 6.68,3.56 \mathrm{~Hz})$. Then, it was observed for corresponding carbon signals in its ${ }^{13} \mathrm{C}-\mathrm{NMR}$ (DEPT) spectrum at $\delta_{C} 135.8$ $(\mathrm{C}-22, \mathrm{CH})$ and $\delta_{\mathrm{C}} 131.7(\mathrm{C}-23, \mathrm{CH})$, respectively. The ${ }^{13} \mathrm{C}-\mathrm{NMR}$ spectra of compound exhibited 29 carbon signals including six methyls, nine methylenes, seven methenyl and three olefinic carbons, three quaternary carbon atoms, and one ester carbonyl carbon. Compound $\mathbf{2}$ was then identified as $3 \beta$-acetate,5(6)-22(23)-cholestadien by comparison of spectroscopic data in literature [10]. For the optical rotations and ${ }^{1} \mathrm{H}-\mathrm{NMR}$ spectrum of the metabolite 2 from Buthus martensii kirsch, that it was in agreement with the chemical structures of the corresponding CAS Registry Number 1089664-70-9 of SciFinder Scholar [11]. Therefore, the absolute configuration of compound 2 should be $(-) 7 S, 8 S, 9 R$, 13R, 14S, 17R, 20S-(22E)-3ß-acetate, 5(6)-22E-(23)-cholestadien, shown in Figure 4. The ${ }^{1} \mathrm{H}-\mathrm{NMR}$ and ${ }^{13} \mathrm{C}-\mathrm{NMR}$ data assignment of compound 2 was shown in Table 1. 


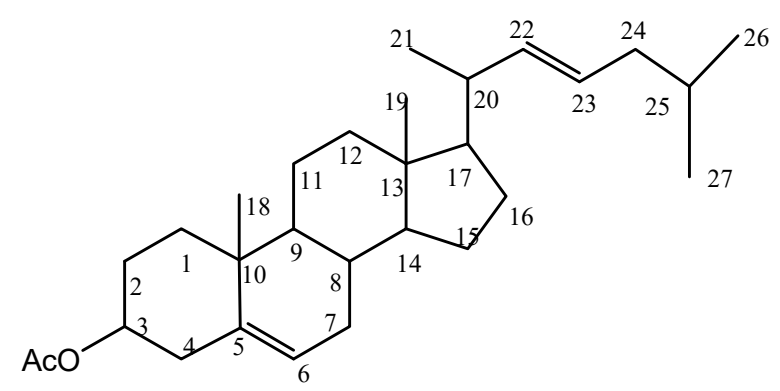

Figure 4. Structure of isolated compound 2.

Compound 3 (QX3-2-7) was isolated as a colorless oil, $[\alpha]_{D}^{25}=-15.2^{\circ}\left(\mathrm{c}, 0.10, \mathrm{CHCl}_{3}\right)$. The molecular formula was determined as $\mathrm{C}_{15} \mathrm{H}_{25} \mathrm{O}_{3}$ from HR-ESIMS at $m / z 253.1796[\mathrm{M}+\mathrm{H}]^{+}$ (calcd. for 253.1798). IR spectrum suggested the presence of carboxyl acid for carbonoxyl group $\left(1721 \mathrm{~cm}^{-1}\right)$, double bond (1642 and $\left.1460 \mathrm{~cm}^{-1}\right)$ and hydroxyl group (3300-2500 and $\left.1327 \mathrm{~cm}^{-1}\right)$. The ${ }^{1} \mathrm{H}-\mathrm{NMR}\left(400 \mathrm{MHz}, \mathrm{CDCl}_{3}\right.$ ) spectrum exhibited that the compound has two methyl signals both $0.87(3 \mathrm{H}, \mathrm{s})$ and $0.88(3 \mathrm{H}, \mathrm{s})$, saturated protons signals in high field between 1.26 and 2.30. In addition, an unsaturated protons signal at $\delta_{H} 5.34(\mathrm{br}, 1 \mathrm{H})$ and one activity hydrogen signal was at $\delta_{H} 7.54$ (br, $1 \mathrm{H})$. The ${ }^{1} \mathrm{H}^{1}{ }^{1} \mathrm{H}$ COSY of compound 3 revealed the cross correlation signals of two spin systems between H-2/ H-3, H-2' ${ }^{\prime}$ H-3 ${ }^{\prime}, \mathrm{H}-4^{\prime}\left(\delta_{H} 5.34 / 2.01 / 1.26 / 2.30\right)$, and H-7/H-6, H-5 $\left(\delta_{H} 0.87 / 1.62 / 2.01\right)$, indicating the existence of two substituents of the methyl group and saturated chains hydrocarbon on the ring (in Figure 5.) The ${ }^{13} \mathrm{C}-\mathrm{NMR}$ and DEPT $\left(100 \mathrm{MHz}, \mathrm{CDCl}_{3}\right)$ spectra (Table 2) displayed resonances for 15 carbon signals categorized as two methyls as $\delta_{C} 14.0(\mathrm{C}-7)$ and $14.1\left(\mathrm{C}-1^{\prime}\right)$, one double bond signal at $\delta_{C} 130.0(\mathrm{C}-1)$ and 129.7 (C-2), a saturated carboxylic acid signal at $\delta_{C} 179.1$, and a quaternary-oxygen carbon signal at $\delta_{C} 77.2(\mathrm{C}-6)$, another nine carbon signals at $\delta_{C} 22.7\left(\mathrm{CH}_{2}\right), 24.9$ $\left(\mathrm{CH}_{2}\right), 27.2\left(\mathrm{CH}_{2}\right), 29.1(\mathrm{CH}), 29.3(\mathrm{C}), 29.5\left(\mathrm{CH}_{2}\right), 29.7\left(\mathrm{CH}_{2}\right), 32.0\left(\mathrm{CH}_{2}\right)$, and $34.1\left(\mathrm{CH}_{2}\right)$. The above mentioned data indicated that compound 3 possessed a $\alpha$-bisaboleneol skeleton structure $[12,13]$. It can be inferred that a monocyclic terpene alcohol compound with a saturated carboxylic acid substituent and a hydroxyl group with active hydrogen was located at C-6, which correlation cross-signal $\delta_{H}$ $5.34 / \delta c 77.2$ was observed in the HSQC and HMBC spectrum, respectively; along with the ESI-HRMS indicated that structure of compound 3 was confirmed. The occurrence of a 6-hydroxy-7-methyl monocyclic terpene-1(2) moiety was demonstrated by the HMBC correlations from H-7 $\left(\delta_{H} 0.87\right)$ to C-6 ( $\delta c 77.2), C-2(\delta c 129.7)$, and C-3 ( $\delta c 27.2)$, and from H-2 ( $\left.\delta_{H} 5.34\right)$ to C-1 ( $\left.\delta c 130.0\right), C-3(\delta c 27.2)$. The saturated carboxylic group of substituent located at $C-4$ of the $\beta$-bisaboleneol ring, of which was substantiated by the observed HMBC cross-peaks of H-2' $\left(\delta_{H} 1.26\right)$ to C-4 ( $\left.\delta c 29.5\right)$, from H-3' $\left(\delta_{H} 2.30\right)$ to $\mathrm{C}-5(\delta c 24.9), \mathrm{C}-4^{\prime}(\delta c 32.0)$ and from $\mathrm{H}-7^{\prime}\left(\delta_{H} 1.26\right)$ to $\mathrm{C}-5^{\prime}(\delta c 29.5)$ and $\mathrm{C}-4^{\prime}(\delta c 32.0)$. Therefore, the ${ }^{1} \mathrm{H}-\mathrm{NMR}$ and ${ }^{13} \mathrm{C}-\mathrm{NMR}$ data assignment of compound 3 was shown in Table 2 . The ${ }^{1} \mathrm{H}_{-}{ }^{1} \mathrm{H}$ COSY correlations and key HMBC correlations for compound 3 shown in Figures 5 and 6, respectively.

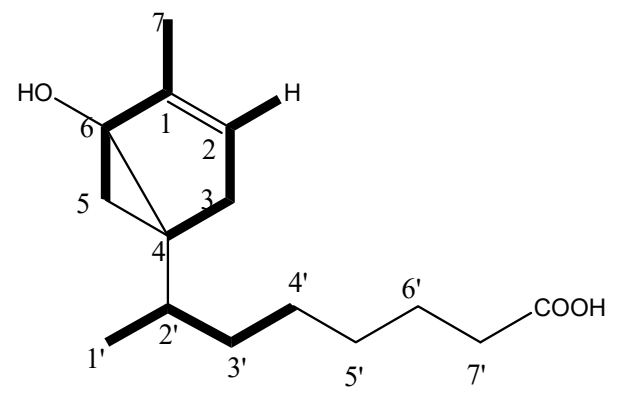

Figure 5. Key ${ }^{1} \mathrm{H}^{-1} \mathrm{H}$ Cosy correlations of compound 3. 
Table 2. ${ }^{1} \mathrm{H}-\mathrm{NMR}(400 \mathrm{MHz})$ and ${ }^{13} \mathrm{C}-\mathrm{NMR}(100 \mathrm{MHz})$ data of compound 3 (in $\mathrm{CDCl}_{3}$ ).

\begin{tabular}{cccc}
\hline No. & $\delta_{H}(\boldsymbol{J}, \mathrm{Hz})$ & $\boldsymbol{\delta}_{\boldsymbol{c}}(\mathrm{DEPT})$ & HMBC \\
\hline 1 & & $130.0(\mathrm{C})$ & \\
2 & $5.34(1 \mathrm{H}$, br. s) & $129.7(\mathrm{CH})$ & $\mathrm{H}-2 / \mathrm{C}-3, \mathrm{C}-1$ \\
3 & $2.01(2 \mathrm{H}$, br. s) & $27.2\left(\mathrm{CH}_{2}\right)$ & $\mathrm{H}-3 / \mathrm{C}-2, \mathrm{C}-2^{\prime}$, \\
4 & & $29.3(\mathrm{C})$ & \\
5 & $1.62(2 \mathrm{H}$, br. s) & $24.9\left(\mathrm{CH}_{2}\right)$ & \\
6 & & $77.2(\mathrm{C})$ & $\mathrm{H}-7 / \mathrm{C}-6$ \\
7 & $0.87(3 \mathrm{H}, \mathrm{s})$ & $14.0\left(\mathrm{CH}_{3}\right)$ & $\mathrm{H}-7 / \mathrm{C}-3, \mathrm{C}-2$ \\
$1^{\prime}$ & $0.88(3 \mathrm{H}, \mathrm{s})$ & $14.1\left(\mathrm{CH}_{3}\right)$ & \\
$2^{\prime}$ & $1.26(1 \mathrm{H}$, br. s) & $29.1\left(\mathrm{CH}^{\prime}\right)$ & $\mathrm{H}-2^{\prime} / \mathrm{C}-4$ \\
$3^{\prime}$ & $2.30(2 \mathrm{H}$, br. s) & $34.1\left(\mathrm{CH}_{2}\right)$ & $\mathrm{H}-3^{\prime} / \mathrm{C}-5, \mathrm{C}-4^{\prime}$ \\
$4^{\prime}$ & $1.26(2 \mathrm{H}$, br. s) & $32.0\left(\mathrm{CH}_{2}\right)$ & $\mathrm{H}-4^{\prime} / \mathrm{C}-1^{\prime}$ \\
$5^{\prime}$ & $1.26(2 \mathrm{H}$, br. s) & $29.5\left(\mathrm{CH}_{2}\right)$ & \\
$6^{\prime}$ & $1.26(2 \mathrm{H}$, br. s) & $29.7\left(\mathrm{CH}_{2}\right)$ & \\
$7^{\prime}$ & $1.26(2 \mathrm{H}$, br. s) & $22.7\left(\mathrm{CH}_{2}\right)$ & $\mathrm{H}-7^{\prime} / \mathrm{C}-5^{\prime}, \mathrm{C}-4^{\prime}$ \\
$-\mathrm{COOH}$ & $7.50(1 \mathrm{H})$ & $179.1(\mathrm{C})$ & \\
\hline
\end{tabular}
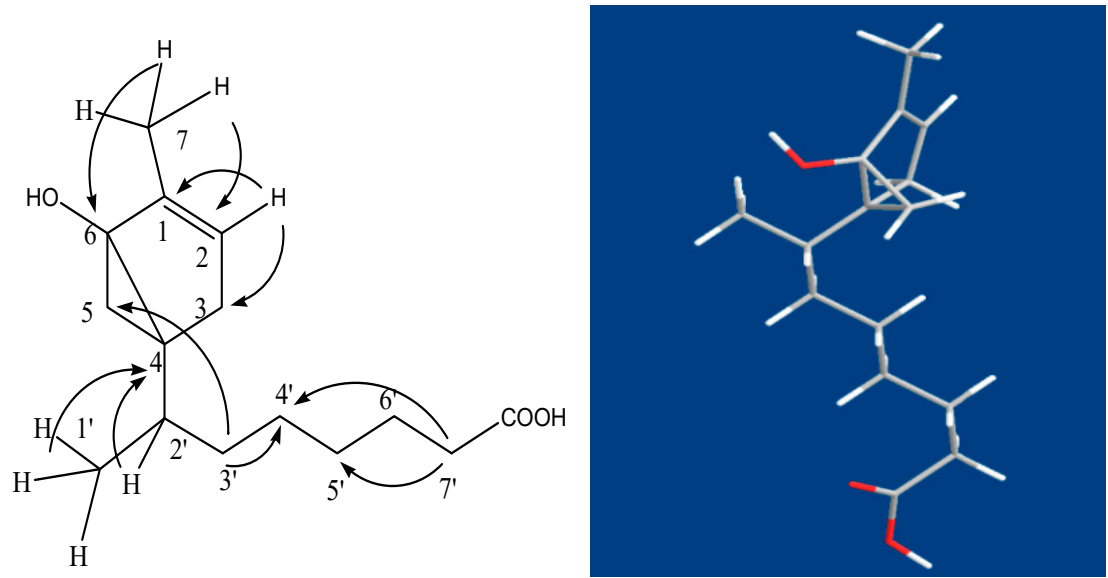

Figure 6. Key HMBC correlations of compound 3.

Therefore, the planar structure of 3 was elucidated as a $\alpha$-bisaboleneol acid and was reasonably assigned as $1 \beta$-methyl-6-hydroxyl-bicyclo[4,2,0]-hex-1-ene- $4 \alpha-\left(2^{\prime}\right.$-methyl)-isooctanoic acid. Analysis of the previously reported bisaboleneol acid revealed that almost all possessed hydroxyl group on ring, and the carboxyl group instead of the end of the carbon chain. However, it shows that compound 3 is a new compound isolated from the arthropods Buthus martensii kirsch, and has not been reported in the literature before.

The absolute configuration of $\mathbf{3}$ was established by comparison of the NOESY experimental with reference to the literature [14] and its CD spectra determined. The NOESY correlations of H-5eq /H-2' eq /H-4', and H-5a/H-3eq (Figure 7a), as well as the coupling constants of H-5 and H-2' value $<10.0 \mathrm{~Hz}$ respectively in ${ }^{1} \mathrm{H}-\mathrm{NMR}$ spectrum in $\mathrm{CDCl}_{3}$ (Table 3) suggested trans-relationship for all of the ortho-position chiral centers. The absolute configurations (Figure $7 \mathrm{~b}$ ) of compound 3 were determined as $(4 S, 6 R)$ by the close agreement between the references and experimental CD spectrum for $223.5 \mathrm{~nm}$ and $250.2 \mathrm{~nm}$ of compound 3. Thus, compound 3 was proved to be a left-handed molecule and named as (-)-1 $\beta$-methyl-6(R)-hydroxyl-bicyclo-[4,2,0]-hex-1-ene- $4 \alpha(S)-\left(2^{\prime}\right.$-methyl)-isooctanoic (Figure 7). 


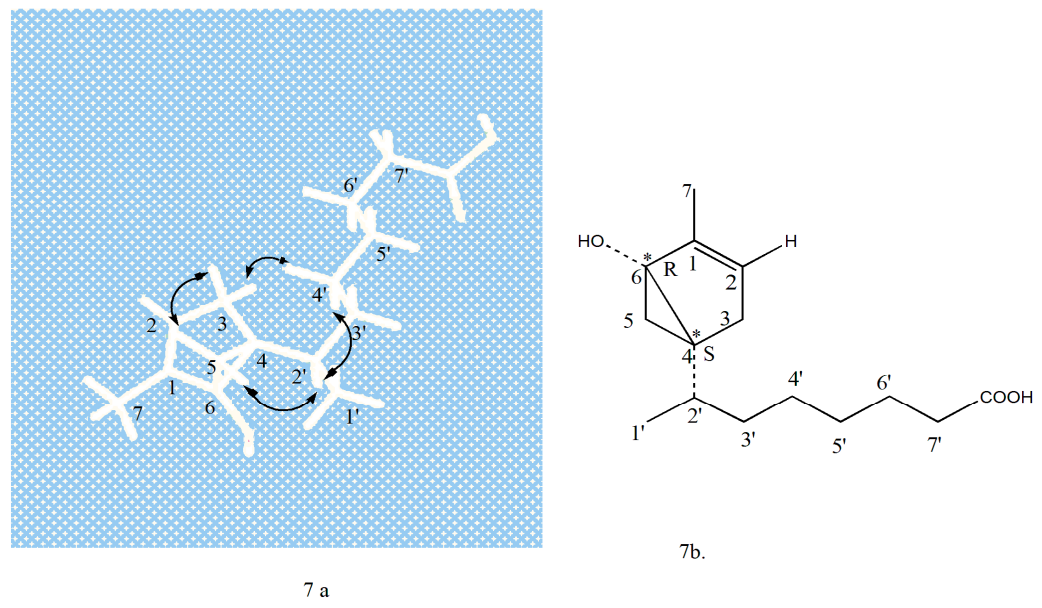

Figure 7. The absolute configuration of compound 3. (a) NOESY correlations of compound 3; (b) The absolute configuration of compound 3 (The asterisk represents the chiral carbon atom).

Table 3. Determination of minimal inhibitory concentration and minimal bactericidal concentration of compounds 1-3 from scorpion, Buthus martensii karsch $(\mu \mathrm{g} / \mathrm{mL})$.

\begin{tabular}{cccccccccc}
\hline \multirow{2}{*}{ Strains } & \multicolumn{2}{c}{ Compound 1 } & \multicolumn{2}{c}{ Compound 2 } & \multicolumn{2}{c}{ Compound 3 } & \multicolumn{2}{c}{ Countrol } \\
\cline { 2 - 9 } & MIC & MBC & MIC & MBC & MIC & MBC & Penicillin G & Gentamycin Vancomycin \\
\hline B. subtilis (ATCC 6051) & 78 & $>128$ & 78 & $>128$ & 256 & $>256$ & - & - & - \\
S. aureus (ATCC 6538) & 78 & $>128$ & 16 & 32 & $>256$ & $>256$ & - & - & - \\
E. coli (ATCC 25922) & 256 & $>256$ & 256 & $>256$ & 256 & $>256$ & - & - \\
P. aeruginosa (ATCC 27853) & 64 & $>78$ & 16 & $<48$ & $>256$ & $>256$ & - & - & - \\
MRSA (Clinical isolated) & 256 & $>256$ & 128 & 256 & $>256$ & $>256$ & - & - \\
\hline
\end{tabular}

"-" in the table means the measurement is meaningless.

\subsection{Assay of Antibacterial and Bactericidal Activities}

The isolated compounds were tested for their antibacterial and germicide activities against four opportunistic pathogen strains-Bacillus subtilis ATCC 6051, Staphylococcus aureus ATCC 6538, Escherichia coli ATCC 25922 and Pseudomonas aeruginosa ATCC 27853-as well as methicillin-resistant Staphylococcus aureus (MRSA) by the two fold serial dilution method [15]. The positive control, penicillin $\mathrm{G}$ (potassium salt, 1598 units per $\mathrm{mg}$ ) gentamycin (sulfate 1000 units per $\mathrm{mg}$ ), and vancomycin (50 units per mg) were purchased from Sigma-Aldrich Ltd., St. Louis, MO, USA.

The results indicated that compounds 1 and 2, both with 5,22E-cholestadienol structure, have a broad antibacterial spectrum against the opportunistic pathogen P. aeruginosa ATCC 27853 and S. aureus ATCC 6538. The minimal inhibitory concentrations (MICs) value of the sample was firstly measured by the dual-dilution method. In order to obtain the effective fungicide leading compound and further determine the MBC value, we selected the MIC value of less than $64 \mu \mathrm{g} / \mathrm{mL}$ for sustainable development and the testing sample. The results showed the significant antibacterial effect for the MIC values of $64 \mu \mathrm{g} / \mathrm{mL}$ of compound 1 against $P$. aeruginosa ATCC 27853 and $78 \mu \mathrm{g} / \mathrm{mL}$ against S. aureus ATCC 6538. Compound 2 displayed the stronger antibacterial effect with the MIC values of $16 \mu \mathrm{g} / \mathrm{mL}$ against both P. aeruginosa ATCC 27853 and S. aureus ATCC 6538. Then, the MBC values of 2 were at $32 \mu \mathrm{g} / \mathrm{mL}$ and less than $48 \mu \mathrm{g} / \mathrm{mL}$, respectively. 5,22E-cholestadienol derivatives (compounds 1 and 2) are small molecules of natural products with the significant inhibitory effects against pathogenic bacteria S. aureus ATCC 6538 and P. aeruginosa ATCC 27853. And MBC/MIC ratios of two compounds were quantified by using a luciferase-based assay [16]. According to the ratio of MBC/MIC, it is possible to identify the antibacterial profile of compounds (bacteriostatic and/or bactericidal). The result shows that compound $\mathbf{2}$ inhibited bacterial growth of both S. aureus and P. aeruginosa in a bactericidal rather than a bacteriostatic manner $(\mathrm{MBC} / \mathrm{MIC}$ ratio $\leq 2)$. Similarly, with compound 1 , a ratio of $\mathrm{MBC} / \mathrm{MIC} \leq 2$ indicates bactericidal activity inhibited bacterial growth of $P$. aeruginosa, whereas a ratio of $\mathrm{MBC} / \mathrm{MIC} \geq 4$ defined a bacteriostatic effect [17]. Interestingly, this suggests that 
these two compounds with 5,22E-cholestadienol structure classified as bactericidal agents against broad spectrum bactericide activities from Buthus martensii karsch, which is a more interesting profile (Table 3). It was thus suggested that compound 2 had the most potent broad-spectrum bactericidal activity and need further investigation into the mechanistic insight. All in vitro experiments were performed in duplicate.

Compound 1 (QX75-5): (-)7S, 8S, 9R, 13R, 14S, 17R, $20 S$ (22E)-3-oxocholesta-4,22(23)-dien-25-ol. [ $\alpha]_{D}^{20}$ $-22.7^{\circ}\left(c, 0.07, \mathrm{CHCl}_{3}\right) ; \mathrm{UV}\left(\mathrm{CHCl}_{3}\right) \lambda_{\max }: 223.5 \mathrm{~nm} ; \mathrm{CD}\left(c, 6.60 \times 10^{-4} \mathrm{M}, \mathrm{CHCl}_{3}\right) \lambda_{\max }(\Delta \varepsilon): 201$ (-9.23), 205 (-13.5), $208(-15.3), 210(-14.1), 214(-12.3), 219(-10.5), 223(-9.420), 229(-8.56), 233$ $(-7.86)$. Positive HR-ESIMS $m / z[\mathrm{M}+\mathrm{H}]^{+} 399.3263$ (calcd. for $399.3258, \mathrm{C}_{27} \mathrm{H}_{43} \mathrm{O}_{2}$ ). IR film ${ }_{\mathrm{cm}-1}$ : 3346, 1678, 1583, 1446, 690. For ${ }^{1} \mathrm{H}-\mathrm{NMR}$ and ${ }^{13} \mathrm{C}-\mathrm{NMR}$ data, see Table 1.

Compound 2 (QX37-45-4): (-) 7S, 8S, 9R, 13R, 14S, 17R, 20S (22E)-3ß-acetate,5 (6)-22E (23)-Cholestadien. $[\alpha]_{D}^{20}-66.7^{\circ}\left(c, 0.10, \mathrm{CHCl}_{3}\right)$; $\mathrm{UV}\left(\mathrm{CHCl}_{3}\right) \lambda_{\max }: 222.5$ and $254.8 \mathrm{~nm}(\mathrm{vw}) ; \mathrm{CD}$ $\left(c, 6.67 \times 10^{-4} \mathrm{M}, \mathrm{CHCl}_{3}\right) \lambda_{\max }(\Delta \varepsilon): 204(-5.84), 209(-12.7), 213(-10.1), 222.5(-8.50), 230(-6.54)$, $236(-4.79)$ and $242(-2.75), 247(-1.44), 254(-0.94), 260(-1.16), 268(-1.94)$. Positive HR-ESIMS $m / z[\mathrm{M}+\mathrm{H}]^{+} 443.3153$ (calcd. for 443.3156, $\mathrm{C}_{29} \mathrm{H}_{47} \mathrm{O}_{2}$ ). IR ${ }_{\mathrm{cm}-1}$ : 3417, 1726, 1640, 1568, 1447. For ${ }^{1} \mathrm{H}-\mathrm{NMR}$ and ${ }^{13} \mathrm{C}-\mathrm{NMR}$ data, see Table 1.

Compound 3 (QX3-2-7): (-) 1 3 -methyl-6 (R) -hydroxyl-bicyclo [4,2,0] hex-1-ene-4 $\alpha$ (S)-(2'-methyl)-isooctanoic. $[\alpha]_{D}^{20}-15.2^{\circ}\left(c, 0.10, \mathrm{CHCl}_{3}\right) ; \mathrm{UV}\left(\mathrm{CHCl}_{3}\right) \lambda_{\max }: 223.5$ and $250.2 \mathrm{~nm}(\mathrm{vw})$; $\mathrm{CD}\left(c, 6.61 \times 10^{-4} \mathrm{M}, \mathrm{CHCl}_{3}\right) \lambda_{\max }(\Delta \varepsilon): 201(+4.15), 206(-9.24), 219(-10.0), 223(-10.5), 227(-9.60)$, $231(-7.92), 236(-6.10)$ and $244(-4.16), 250(-3.06), 260(-2.30)$. Positive HR-ESIMS $m / z[\mathrm{M}+\mathrm{H}]^{+}$ $253.1796[\mathrm{M}+\mathrm{H}]^{+}$(calcd. for 253.1798, $\mathrm{C}_{15} \mathrm{H}_{25} \mathrm{O}_{3}$ ). IR film ${ }_{\mathrm{cm}-1}$ : 3300-2500, 1721, 1642, 1460, 1327. The ${ }^{1} \mathrm{H}-\mathrm{NMR}$ and ${ }^{13} \mathrm{C}-\mathrm{NMR}$ data, see Table 2.

Supplementary Materials can include anything data of reported compounds and they have been designated open access or are freely available online.

\section{Materials and Methods}

\subsection{General Experimental Procedure}

Optical rotations were measured using a JASCO DIP-360 (Tokyo, Japan automatic digital polarimeter). IR and UV spectra were recorded using the JASCOFT-IR 620 spectrophotometer and UV-2600 instrument, respectively. 1D and 2D NMR spectra were recorded on Bruker DRX-400 spectrometer (400 MHz for ${ }^{1} \mathrm{H}-\mathrm{NMR}$, Karlsruhe, Germany) with TMS used as internal standard. The mass spectra were obtained on Agilent Series1100 SL mass spectrometer (Agilent Technologies Inc., Santa Clara, CA, USA), and Bruker Daltonics mass spectrometer (Bruker Daltonics Inc. Billerica, MA, USA) with an electrospray ionization source. Circular Dichroism (CD) was obtained using the Chirascan, Applied Photophysics Ltd. (Surrey, UK). HPLC was performed using a system comprised of a CCPM pump (Tosoh, Tokyo, Japan), a CCP PX-8010 controller (Tosoh), an RI-8010 detector (Tosoh) or a Shodex OR-2 detector (Showa-Denko, Tokyo, Japan), and a Rheodyne injection port. A Capcell Pak C18 UG120 column (10 mm i.d. $\times 250 \mathrm{~mm}, 5 \mu \mathrm{m}$, Shiseido, Tokyo, Japan) was employed for preparative HPLC. Sephadex LH-20 (GE Healthcare Bio-Sciences AB, Uppsala, SE, USA) was used for column chromatography (CC), and a silica gel $\mathrm{GF}_{254}$ (10-40 mm, Haiyang Co., Qingdao, China) was used for preparative TLC as precoated plates. TLC spots were visualized under UV light through dipping into $5 \% \mathrm{H}_{2} \mathrm{SO}_{4}$ in alcohol. All chemicals used were analytical grade.

\subsection{Insect/Animal Materials}

Adult of arthropod scorpions, Buthus martensii karsch $(2.0 \mathrm{~kg})$, were purchased from traditional a Chinese medicine store in Bozhou, Anhui of China in September 2016 and the insect has been identified by Professor Wenliang Li. Whole scorpion B. martensii karsch specimen no. QX2016-9 is currently 
stored in the FuniuMountain Natural Products Resource exhibition hall of Henan University Science and Technology, Luoyang city.

In the antibacterial experiment, four selected pathogenic strains and one resistant strain were commonly used in clinic, including two Gram-positive bacteria (B. subtilis and S. aureus), two Gram-negative bacteria (E. coli and P. aeruginosa), and the multidrug-resistant strain (methicillin-resistant Staphylococcus aureus-MRSA). Four species of standard strains were acquired from Shanghai Biological Research Technology Co., Ltd. (Shanghai, China) and one species of MRSA strains was obtained from clinically isolated drug-resistant strain.

\subsection{Extraction and Isolation}

Air-dried bodies of the scorpion B. martensii karsch were crushed into granules and extracted with $\mathrm{CH}_{2} \mathrm{Cl}_{2}$ to remove insect wax. Using the ultrasonic extraction method, the $70 \%$ methanol extract $(76.00 \mathrm{~g})$ was collected and freeze-dried. The extract was further dissolved in methanol and then separated solid from liquid to obtain methanol extract $(52.10 \mathrm{~g})$. Under the guidance of antimicrobial activity, the $\mathrm{MeOH}$ extracts were then concentrated and isolated by the silica gel column and Sephadex LH-20 column chromatograph with gradient eluted using $\mathrm{CHCl}_{3}: \mathrm{MeOH}(10: 0,9: 1,7: 3,5: 5,3: 7 ; 1: 9$, 0:10) and $\mathrm{MeOH}: \mathrm{H}_{2} \mathrm{O}$. The same fractions were collected to produce Sections I-VI. Section II was purified repeatedly $\left(\mathrm{CHCl}_{3}: \mathrm{MeOH}, 9: 1\right)$ by silica gel column as well as Sephadex $\mathrm{LH}-20$ to produce compound $3(24.62 \mathrm{mg})$. Section IV was further separated $\left(\mathrm{CHCl}_{3}: \mathrm{MeOH}, 7: 3,1.44 \mathrm{~g}\right)$ by preparative HPLC Column: YMC-ODS-AQ $(250 \mathrm{~cm} \times 20 \mathrm{~cm})$; mobile phase $\mathrm{MeOH} / \mathrm{H}_{2} \mathrm{O}(75: 25)$; and flow rate $4 \mathrm{~mL} / \mathrm{min}$, to produce compound $2(29.10 \mathrm{mg})$. Section $\mathrm{V}$ was then separated by preparative HPLC using $\mathrm{MeOH} / \mathrm{H}_{2} \mathrm{O}$ (55:45) to yield compound $\mathbf{1}$ (35.00 mg).

\subsection{Determined Method of Antibacterial and the Bactericidal Activity}

Antibacterial assays were performed using standard bacteria including B. subtilis ATCC 6051, S. aureus ATCC 6538, E. coli ATCC 25922, P. aeruginosa ATCC 27853, and methicillin-resistant Staphylococcus aureus (MRSA). The bacteria were isolated and cultivated using clinical and Laboratory Standards for antimicrobial susceptibility testing [15]. A single colony of bacteria were cultured from a master plate and put into a bottle of $10.0 \mathrm{~mL}$ LB. medium, cultured usually until the bacteria were growing well after shaking at $37^{\circ} \mathrm{C}$ overnight or $28^{\circ} \mathrm{C}$. The UV absorbance was measured at $600 \mathrm{~nm}$ with $1.0 \mathrm{~mL}$ of the culture which the bacterial concentration controlled and determined to each well by ultraviolet spectrophotometer. The corresponding OD values of the different strains were respectively at Abs.600 nm as:

B. subtilis ATCC 6051, A = 0.025; S. aureus ATCC 6538, $\mathrm{A}=0.072 ;$ E. coli $\mathrm{ATCC} 25922, \mathrm{~A}=0.055$; P. aeruginosa ATCC 27853, A = 0.054; and MRSA (clinically isolated strain), A = 0.066.

The main purpose of the study was to determine the in vitro inhibitory and bactericidal activities and the level of tolerance to the three compounds observed by standardized MIC and MBC tests. MICs of each compound were determined by broth two fold serial dilution technique, in accordance with the guidelines of the Clinical and Laboratory Standards Institute [15]. Compounds 1-3 were tested at dilution ranges of $1000,625,312,256,128,78,64,32,16,8,3.12$, to $1.56 \mu \mathrm{g} / \mathrm{mL}$. Standard cation-adjusted penicillin G, gentamycin, and vancomycin were used as positive controls for MIC testing, with $70 \%$ methanol for the negative control of each petri dishes. Quantitative $3 \mu \mathrm{L}$ of the tested sample was added to each well and cultured for $12 \mathrm{~h}$ at $37^{\circ} \mathrm{C}$ or $28^{\circ} \mathrm{C}$. The plate was complemented with $1.00 \%$ tryptone, $0.55 \mathrm{~g}$ yeast extract, $15.00 \mathrm{~g}$ sodium chloride, adjusted to $\mathrm{pH} 7.5$ and then add $1.50 \%$ agar as a semisolid medium for the bacterial detection. MBCs were determined in accordance with the guidelines of the Clinical and Laboratory Standards Institute [18]. The entire volume $100 \mu \mathrm{L}$ of the MIC well and the wells with 4 dilutions above the MIC were spread across the center of a broth agar plate and allowed to dry for $20 \mathrm{~min}$. Then, a sterile spreading rod was used to evenly disperse the inoculum over the entire surface of the plate, which was then incubated at $37^{\circ} \mathrm{C}$ for 24 to $48 \mathrm{~h}$. The MBCs were recorded as the lowest dilution to produce a $99.9 \%$ reduction in growth in comparison to the growth 
of the control. Furthermore, drug resistance can be determined when the tested drug MBC/MIC is at or over 32 times $[19,20]$. Vancomycin and ticlonin have been demonstrated. Vancomycin lacked bactericidal activity (defined as an $\mathrm{MBC} / \mathrm{MIC}$ ratio of $>$ or $=32$ ) against two methicillin-resistant Staphylococcus aureus (MRSA) isolates from patients with bone and joint infection [21,22]. By contrast, MIC values of many strains were consistent with the tolerance in literature reported (MBC/MIC ratios $\geq 32)$ [23].

\subsection{Molecular Docking Study}

Compounds 1 and 2 belong to the 5,22E-cholestadienol derivatives have the broad-spectrum bactericide activity. This work aimed to evaluate the structure-activity relationships and to establish the mode of interaction by receptor-ligand interactions molecular modeling, thus revealing the action mechanism of target molecules.

Computational docking study was performed using PharmMapper method to detect and identify drug targets by Discovery Studio 3.0 (East China University of Science \& Technology, and Shanghai institute of medicine, Chinese academy of sciences, Shanghai, China) [24]. Based on the possible targets screened, the target protein 2XRL of the doxycycline was found as the broad-spectrum antibiotics receptor [25] and 1Q23 protein of fusidic acid was the Gram-positive cocci receptor [26,27]. Both antibiotics structural was shown in Figure 8. According to the antibiotic drug doxycycline and the corresponding target protein (PDB ID: 2XRL) binding model, and fusidic acid with target protein (PDB ID: 1Q23) binding model, compounds $\mathbf{1}$ and $\mathbf{2}$ were further studied by molecular docking.<smiles>CC1c2cccc(O)c2C(=O)C2=C(O)C3(O)C(=O)C(C(N)=O)=C(O)C(N(C)C)C3(O)C2C1O</smiles>

(a). doxycycline

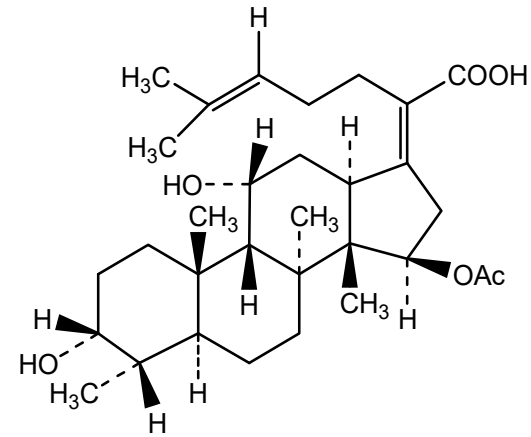

(b). fusidic acid

Figure 8. The structural of positive control drugs (a,b). (a) doxycycline (broad-spectrum antibiotic) and (b) fusidic acid (antibiotic of Gram-positive cocci infection).

Through some related data mining and receptor ligand interaction verification, drug targets of compounds $\mathbf{1}$ and $\mathbf{2}$ can be predicted involving the hydrogen bonds, electrostatic forces, van der Waals forces, etc., and the lead compound with 5,22E-cholesterol derivatives structure can be confirmed for the compounds $\mathbf{1}$ or $\mathbf{2}$. The active site of the target protein of two compounds had the broad-spectrum bactericide proteins 2XRL and anti-G+ bacteria 1Q23, which there were PDB site displayed in Figure 9. Regions of active site were functionally defined and confirmed independently through automatically parameters correction of the image processing computer. 


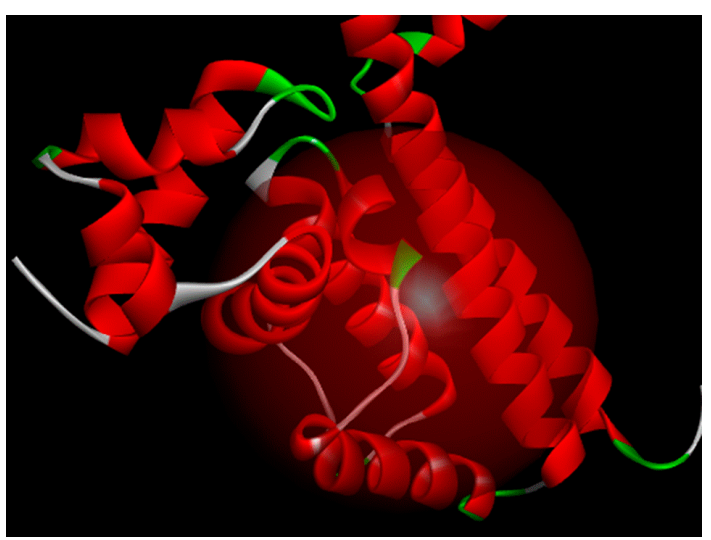

(a)

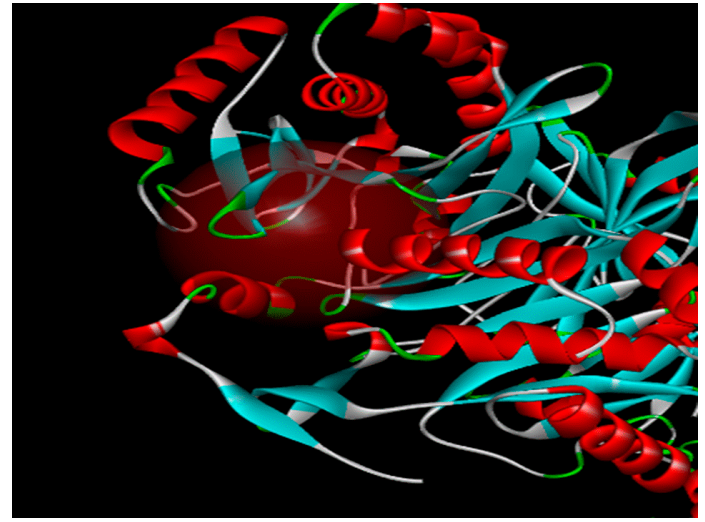

(b)

Figure 9. The red globular region in the figure shows the location of the target protein active site. (a) Active site of target protein 2XRL (target protein receptor of doxycycline) and (b) active site of target protein 1Q23 (target protein receptor of Fusidic acid).

The antibacterial activity of 5,22E-cholesteric compounds 1 and 2 was studied by reverse molecular docking. The doxycycline of an antibiotic clinically used in sensitive bacterial infection was used as reference. The $2 X R L$ protein receptor of doxycycline is a homodimer and its catalytic site located in the active site BC4 of multiple areas (Figure 9a). A 3D graphic description of the docking structures for compounds 1 and 2 are shown in Figure 10.

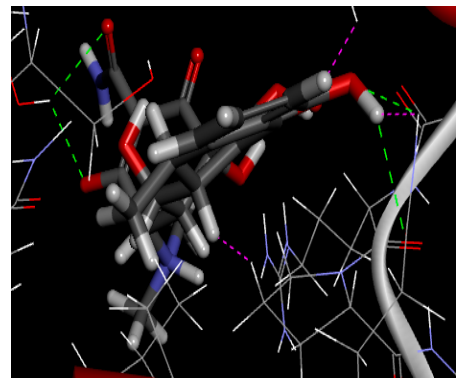

(a)

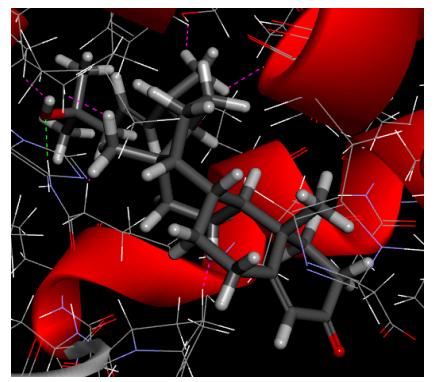

(b)

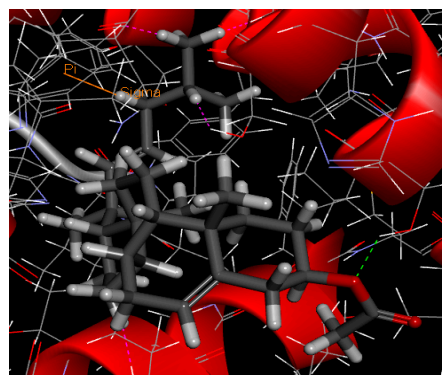

(c)

Figure 10. 3D docking of ligand-receptor interactions with doxycycline as a control. (a) The graphical representation of 3D interaction of doxycycline and receptor protein 2XRL; (b) the graphical representation of $3 \mathrm{D}$ interaction of compound 1 and receptor protein $2 \mathrm{XRL}$; and (c) the graphical representation of 3D interaction of compound 2 and receptor protein 2 XRL.

We can observe the scores ranking after molecular docking on the molecular absolute Energy, Conf. Number, Relative Energy, and LibDock in electrostatic 2D structure (Table 4). The docking study showed that compound 2 presented a good score (98.2142), which is close to the score of the reference doxycycline control (99.0843). These results are in concordance with that obtained on in vitro assays (Table 3). Actual antimicrobial activity of compound 2 is stronger than compound 1. A 2D graphic description of the ligand and receptor protein interactions is shown in Figure 11.

Table 4. The docking parameter table of ligands and the receptor protein 2XRL.

\begin{tabular}{ccccc}
\hline Ligand Name & Absolute Energy & Conf Number & Relative Energy & LibDock Score \\
\hline Doxycycline & 76.5451 & 2 & 2.29878 & 99.0843 \\
Compound 1 & 50.3676 & 38 & 10.4028 & 94.1788 \\
Compound 2 & 54.5212 & 55 & 9.67329 & 98.2142 \\
\hline
\end{tabular}




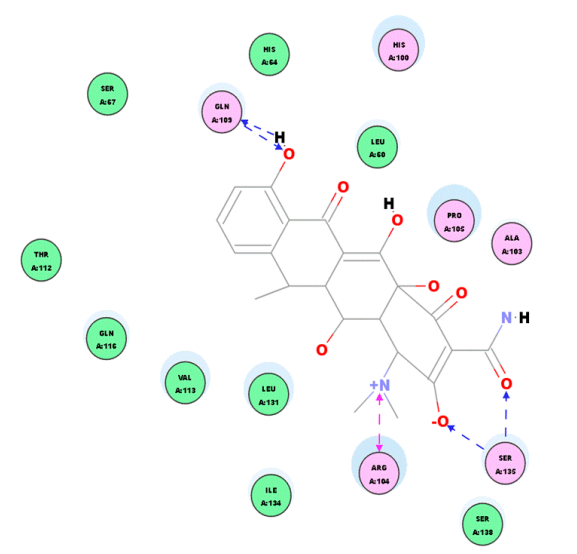

(a)

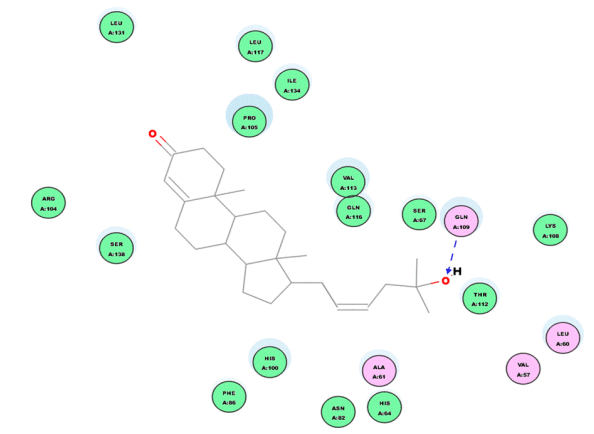

(b)

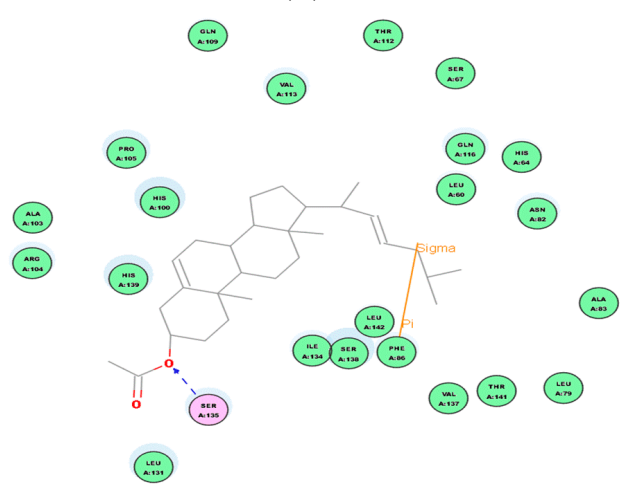

(c)

Figure 11. Ligand interaction of compounds 1, 2 in the active site of target protein 2XRL. (a) 2D intermolecular forces and interaction of doxycycline and receptor protein 2XRL. (b) 2D intermolecular forces interaction of compound 1 receptor protein 2XRL. (c) 2D intermolecular forces interaction of compound 2 receptor protein 2 XRL.

Although these new compounds are not as strong as the effective antimicrobial agents doxycycline, we made the hypothesis that compounds 1 and $\mathbf{2}$ could be the bactericide overcoming the issues of bacterial resistance through covalent binding interactions between their binding site and the receptor protein. The interaction between each compound and the key amino acids residues of the active site of 2XRL can be clearly seen from 2D diagram of chemical bonding interaction (Figure 11). Molecular docking of compounds showed important van der Waals and hydrogen binding interaction with active pocket of amino acid residues as GlnA:109 and SerA:135 from doxycycline receptor proteins; compound 1 displayed the hydrogen binding interaction with GlnA:109 and van der Waals force; however, there were residues inthe SerA:135 hydrogen binding and $\pi-\pi$ interaction of PheA:86 in compound 2, which would be a good explanation that 5,22E-cholestadienol compounds have 
the broad-spectrum of antibacterial activity and the different levels of inhibition are related to the interaction strength of those compounds.

Secondly, based on the evaluation of the same skeleton antibiotic fusidic acid from PDB ID: 1Q23 (Figure 9b), the target molecular docking was used to demonstrate mechanisms of 5, 22E-cholestadienol compounds 1 and 2 against Gram-positive bacteria S. aureus ATCC 6538. The receptor protein 1Q23 of Fusidic acid bond site with amino acid residues for active pocket or catalytic site is located on the active site AC1 of multiple areas (Figure 9b). A 2D graphic description of the docking fusidic acid as a control for compounds $\mathbf{1}$ and $\mathbf{2}$ is shown in Figure 12. The docking site and binding of fusidic acid was selected as reference.

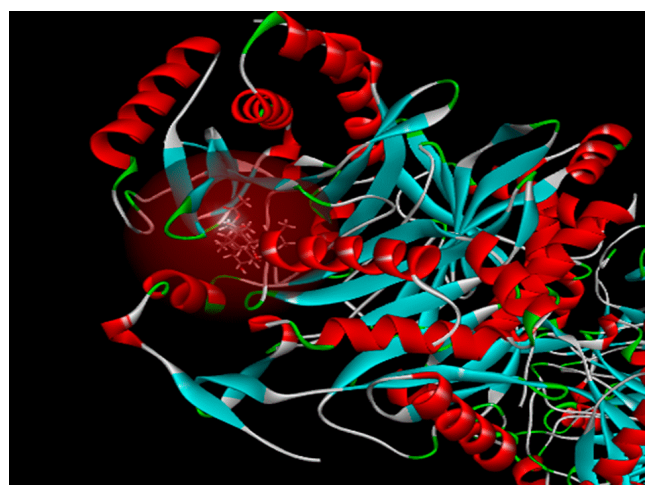

(a)

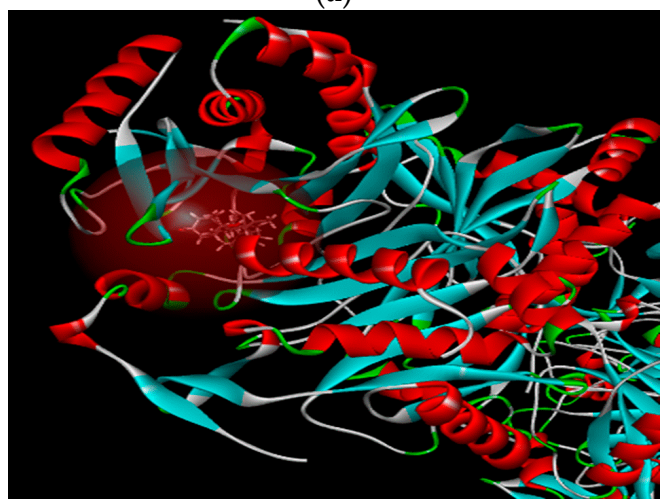

(b)

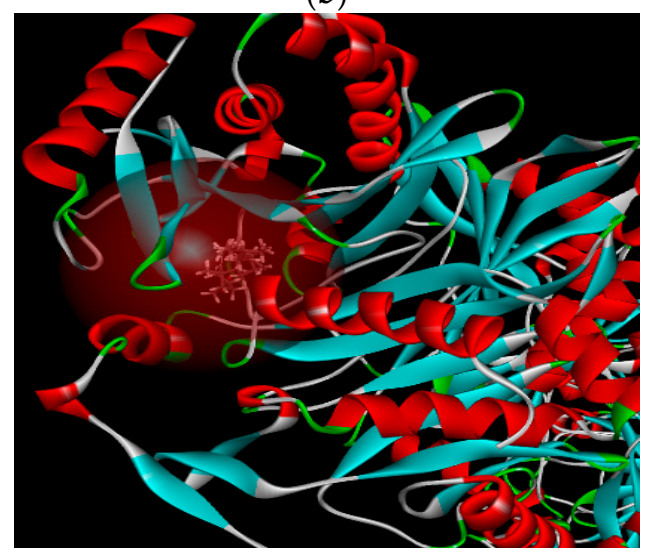

(c)

Figure 12. 2D docking dimensions of ligand-receptor interactions with fusidic acid as a control. (a) 2D interaction models of fusidic acid and receptor protein 1Q23. (b) 2D interaction models of compound 1 and receptor protein 1Q23. (c) 2D interaction models of compound 2 and receptor protein 1Q23.

Compounds 1 and 2 had scores of 124.669 and 125.637, respectively (Table 5). These scores reveal that the chemical binding force of the extract substances is superior to the score of antibiotics fluidic 
acid (122.250). These results are in concordance with those obtained on the in vitro assays (Table 3). A 2D graphic description of the ligand interactions are shown in Figure 12.

Table 5. The docking parameter table of ligand and the receptor proteins 1Q23.

\begin{tabular}{ccccc}
\hline Ligand Name & Absolute Energy & Conf Number & Relative Energy & LibDock Score \\
\hline Fusidic acid & 92.4881 & 51 & 13.1839 & 122.250 \\
Compound 1 & 60.4528 & 81 & 15.6049 & 124.669 \\
Compound 2 & 47.9485 & 22 & 7.98374 & 125.637 \\
\hline
\end{tabular}

Table above indicates that compounds $\mathbf{1}$ and $\mathbf{2}$ are very strong antimicrobial agents even compared to a positive control. Based on the receptor-ligand interactions of compounds 1, 2 and the control with the active site of target protein 1Q23, the antibacterial activities and mechanism of action in the 2D diagram of chemical bonding interaction are evident (Figure 13). Molecular docking of compounds showed important Van der Waals and hydrogen binding interaction with active pocket of amino acid residues as SerG:146 and ThruG:172 between fusidic acid and receptor proteins 1Q23; compound 1 displayed the stranger hydrogen binding interaction with HisH:193 Sigma-Pi interaction and Van der Waals force; compound $\mathbf{2}$ had similar Van der Waals force and Sigma-Pi interaction of TyrJ:33 with the amino acid residues. Therefore, compound $\mathbf{2}$ is another strong Gram-positive bactericide according to the discovery of molecular docking mechanism, which explains the strong bactericidal activity against S. aureus ATCC 6538 of compound 2 , which was observed in the previous antibacterial experiments with MICs of $16 \mu \mathrm{g} / \mathrm{mL}$ and MBCs of $32 \mu \mathrm{g} / \mathrm{mL}$.

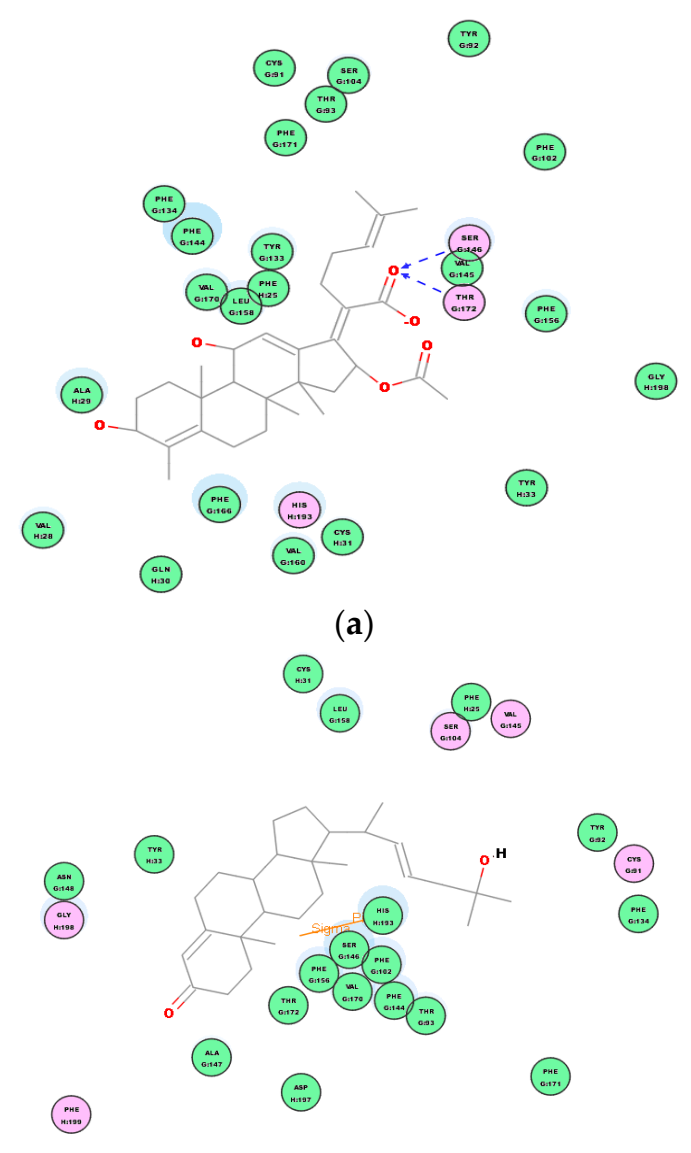

(b)

Figure 13. Cont. 


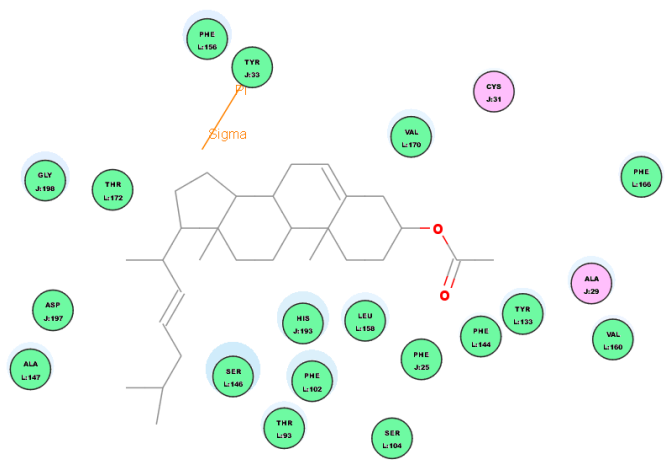

(c)

Figure 13. The chemical bonds and intermolecular forces of ligand compounds $\mathbf{1}$ and $\mathbf{2}$ in the active site of target protein 1Q23. (a) 2D intermolecular forces interaction of fusidic acid and receptor protein 1Q23. (b) 2D intermolecular forces interaction of compound 1 and receptor protein 1Q23. (c) 2D intermolecular forces interaction of compound 2 and receptor protein 1Q23.

\section{Conclusions}

Currently, there is great interest in the study of insects and related arthropods to develop new natural products for various medicinal purposes. In this work, we found three new compounds from the crude extract of scorpion Buthus martensii karsch. Among them, compounds $\mathbf{1}$ and $\mathbf{2}$ of the $5,22 E$-cholestadienol derivatives were identified as broad-spectrum bactericides, and their activity showed significant concentration-dependent effects against Staphylococcus aureus ATCC 6538 and Pseudomonas aeruginosa ATCC 27853.

Compound 2 was found to fit well in the active site of binding pocket both target proteins (PDB ID:2XRL and PDB ID:1Q23) from the chemical bonds formed intermolecular forces. This molecular docking study demonstrated that compound $\mathbf{2}$ is an effective lead compound for natural antibiotics, whether it is as a broad-spectrum antibiotic potence. The antibacterial mechanism is the specific binding (various of bonding forces between molecules) using compound 2 as a ligand based on the different receptor proteins $2 X R L$ or 1Q23 active sites from bacterial ribosome unit A, and thus prevent the synthesis of bacterial proteins. This unique mechanism avoids the cross-resistance issues of other antibacterial drugs.

In the present stereochemical studies, we established molecular configuration of new compounds 1 and 3. The absolute configurations of compound 1 were confirmed by comparing the known chiral analogs of C-24R orientation ( $24 \alpha$ for the ethyl group) with its $J$ value analysis of chemical correlation between H-17ax and H-20eq in the ${ }^{1} \mathrm{H}-\mathrm{NMR}$ spectrum of compound 1. Similarly, the absolute configuration of compound 3 proposed the $\alpha$-bisaboleneol structure as a reference on the Raharivelomanana's group, and we report the stereochemical determination of compound 3. Furthermore, The CD spectra data of compounds 1-3 also fully support the stereochemical assignments.

Supplementary Materials: The following are available online.

Author Contributions: W.Y. and B.L. conceived and initiated the work. B.L. and J.G. planned the experiments and drafted the manuscript. K.L. performed the chemical composition analyses. B.L., H.L., J.B., and Q.Y. collected the bacterial strains and performed the antibacterial and bactericidal activity experiments. W.Y. and J.G. reviewed and edited the manuscript. All authors critically edited the manuscript before submission.

Funding: This work was supported by the National Natural Science Foundation of China (Grant No. 21472035).

Acknowledgments: The authors are grateful for Weiguo Zhu and Jianye Zhang at the Analysis and Test Center of Zhengzhou University for the NMR measurements, elemental analyses, and MS measurements.

Conflicts of Interest: The authors declare no conflict of interest. 


\section{References}

1. Dossey, A.T. Insects and their chemical weaponry: New potential for drug discovery. Nat. Prod. Rep. 2010, 27, 1737-1757. [CrossRef] [PubMed]

2. Matthew, G.; Schroeder, F.C. Comprehensive natural products II. Insect Natural Products; Elsevier: Oxford, UK, 2010; pp. 67-103.

3. Simon, L.; Ruqaiyyah, S.; Naveed, A.K. Animals living in polluted environments are potential source of antimicrobials against infectious agents. Pathog. Glob. Health 2012, 106, 218-223.

4. Niu, L.L.; Gao, J.Y.; Li, H.D.; Liu, J.N.; Yin, W.P. Novel skeleton compound Allomyrinanoid A and two purine alkaloids from the adult of Allomyrina dichotoma L. Bioorg. Med. Chem. Lett. 2016, 26, 366-369. [CrossRef] [PubMed]

5. Song, Z.W.; Liu, P.; Yin, W.P.; Jiang, Y.L.; Ren, Y.L. Isolation and identification of antibacterial neo-compounds from the red ants of ChangBai Mountain, Tetramorium sp. Bioorg. Med. Chem. Lett. 2012, 22, $2175-2181$. [CrossRef] [PubMed]

6. Gao, J.Y.; Yin, W.P.; Gao, T.; Deng, R.X.; Li, X. Two bioactive compounds from the Chinese Scorpion Buthus martensi Karsch. Nat. Prod. Res. 2014, 28, 698-703. [CrossRef] [PubMed]

7. Reich, H.J.; Jautelat, M.; Messe, M.T.; Weigert, F.J.; Roberts, J.D. 13C Nuclear magnetic resonance spectrum of gramicidin S-A, a decapeptide antibiotic. J. Am. Chem. Soc. 1969, 91, 7445-7454. [CrossRef]

8. Mellado, G.G.; Zubã, A.E.; Ortega, M.J.; LÃ ${ }^{3}$ pez-GonzÃ lez, P.J. Steroids from the antarctic octocoral An-thomastus bathyproctus. J. Nat. Prod. 2005, 68, 1111-1115. [CrossRef]

9. Echigo, S.; Castellanos, L.; Duque, C.; Uekusa, H.; Hara, N. C-24 stereochemistry of marine Sterols: (22E)-24-Ethyl-24-methylcholesta-5,22-dien-3 $\beta$-ol and -24-Ethyl-24- methylcholest-5-en-3 $\beta$-ol. J. Braz. Chem. Soc. 1991, 22, 997-1005. [CrossRef]

10. Koreeda, M.; Harada, N.; Nakanishi, K. Exciton chirality method as applied to conjugated enones, esters, and lactones. J. Am. Chem. Soc. 1974, 96, 266-268. [CrossRef]

11. CAS Registry Number: 1089664-70-9, (3ß-acetate, 20S, 22E)-Cholesta-5,22-dien-3-ol. in SciFinder. Available online: https:/ / m.chemsrc.com/en/cas/23515-91-5_943583.html (accessed on 4 November 2018).

12. Raharivelomanana, P.; Robert, F.; Cambon, A.; Azzaro, M. $\beta$-Acoradienol, a sesquiterpene alcohol from Neocallitropsis pancheri. J. Nat. Prod. 1992, 55, 235-236. [CrossRef]

13. Herz, W.; Sharma, P. Pycnolide, a seco-germacradienolide from Liatris pycnostachya, and other antitumor constituents of Liatris species. J. Org. Chem. 1976, 41, 1248-1253. [CrossRef] [PubMed]

14. CAS Registry Number: (1) 87978-39-0; (2) 123887-29-6; in SciFinder. Available online: https:/ / m.chemsrc. com/en/cas/7779-73-9_1118571.html (accessed on 4 November 2018).

15. Ferraro, M.J.; Craig, W.A.; Dudley, M.N.G.; Eliopoulos, M.; Hecht, D.W.; Handler, J.; Roller, L.B.; Sheldon, A.T.; Swenson, J.M.; Ten over, F.C.; et al. Performance Standards for Antimicrobial Susceptibility Testing; 11th Informational Supplement; National Committee for Clinical Laboratory Standards: Wayne, PA, USA, 2000.

16. Ayala-Núñez, N.V.; Villegas, H.H.L.; Turrent, L.d.C.I.; Padilla, C.R. Silver nanoparticles toxicity and bactericidal effect against methicillin-resistant Staphylococcus aureus: Nanoscale does matter. NanoBiotechnology 2009, 5, 1-9. [CrossRef]

17. Konaté, K.; Mavoungou, J.F.; Lepengué, A.N.; Samseny, R.R.R.A.; Hilou, A.; Souza, A.; Dicko, M.H.; M'Batchi, B. Antibacterial activity against $\beta$-lactamase producing Methicillin and Ampicillin-resistants Staphylococcus aureus: Fractional inhibitory concentration index (FICI) determination. Ann. Clin. Microbiol. Antimicrob. 2012, 11. [CrossRef] [PubMed]

18. Clinical and Laboratory Standards Institute. Methods for Determining Bactericidal Activity of Antimicrobial Agents; Approved Guideline; Clinical and Laboratory Standards Institute: Wayne, PA, USA, 1999.

19. May, J.; Shannon, K.; King, A.; French, G. Glycopeptide tolerance in Staphylococcus aureus. J. Antimicrob. Chemother. 1998, 42, 189-197. [CrossRef] [PubMed]

20. Maria, M.; Traczewski, B.D.; Katz, J.N.S.; Steven, D.B. Inhibitory and bactericidal activities of Daptomycin, Vancomycin, and Teicoplanin against Methicillin-Resistant Staphylococcus aureus isolates collected from 1985 to 2007. Antimicrob. Agents Chemother. 2009, 53, 1735-1738. 
21. Rouse, M.S.; Steckelberg, J.M.; Patel, R. In vitro activity of ceftobiprole, daptomycin, linezolid, and vancomycin against methicillin-resistant staphylococci associated with endocarditis and bone and joint infection. Diagn. Microbiol. Infect. Dis. 2007, 58, 363-365. [CrossRef] [PubMed]

22. Nicholas, S.B.; Nimish, P.; Theresa, I.S.; Wissam, I.E.; Atrouni, R.T.H.; Molly, E.S. Relationship between vancomycin tolerance and clinical outcomes in Staphylococcus aureus bacteraemia. J. Antimicrob. Chemother. 2017, 72, 535-542.

23. Biedenbach, D.J.; Bell, J.M.; Sader, H.S.; Fritsche, T.R.; Jones, R.N.; Turnidge, J.D. Antimicrobial. susceptibility of Gram-positive bacterial isolates from the Asia-Pacific region and an in vitro evaluation of the bactericidal activity of daptomycin, vancomycin, and teicoplanin: A SENTRY Program Report (2003-2004). Int. J. Antimicrob. Agents 2007, 30, 143-149. [CrossRef] [PubMed]

24. Liu, X.; Ouyang, S.; Yu, B.; Liu, Y.; Huang, K.; Gong, J.; Zheng, S.; Li, Z.; Li, H.; Jiang, H. PharmMapper server. Nucleic Acids Res. 2010, 38, W609-W614. [CrossRef] [PubMed]

25. Yang, C.; Yuan, Z.; Huang, W.X.; Zheng, X.P. A clinical trial of doxycyclinc hydrochloride for injection in the treatment of acute bacterial infections. Chin. J. Antibiot. 2006, 31, 675-678. (In Chinese)

26. Abouelfetouh, A.; Kassem, M.; Naguib, M.; El-Nakeeb, M. Investigation and treatment of fusidic acid resistance among Methicillin-Resistant Staphylococcal isolates from Egypt. Micro. Drug Resis. 2017, 23, 8-17. [CrossRef] [PubMed]

27. Farrell, D.J.; Mendes, R.E.; Castanheira, M.; Jones, R.N. Activity of Fusidic acid tested against Staphylococci isolated from Patients in US Medical Centers in 2014. Antimicrob. Agents Chemother. 2016, 60, 3827-3831. [CrossRef] [PubMed]

Sample Availability: Samples of the compounds 1, 2 and 3 are available from the authors.

(C) 2018 by the authors. Licensee MDPI, Basel, Switzerland. This article is an open access article distributed under the terms and conditions of the Creative Commons Attribution (CC BY) license (http://creativecommons.org/licenses/by/4.0/). 